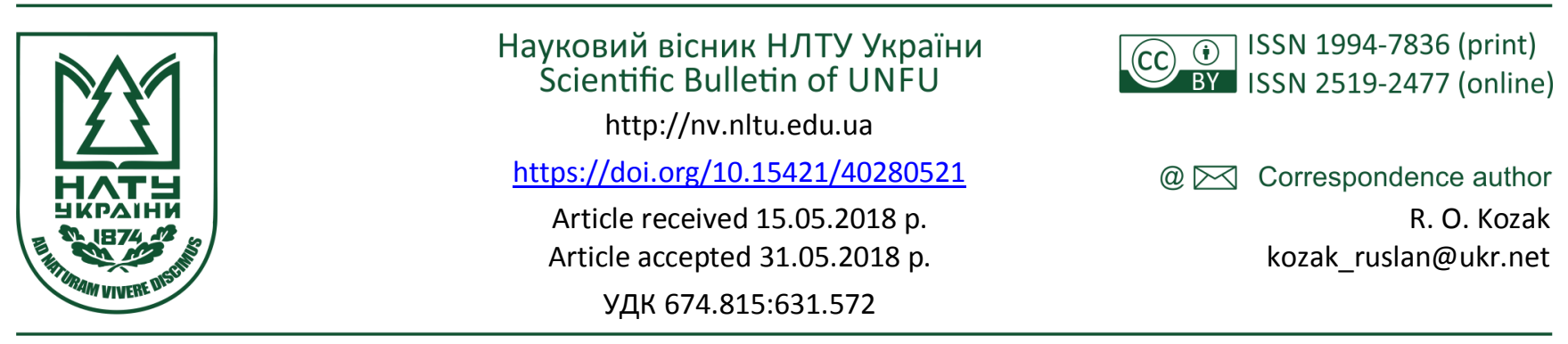

Р. О. Козак, П.А. Бехта

Національний лісотехнічний університет України, м. Львів, Украйна

\title{
ПОКРАЩЕННЯ ВЛАСТИВОСТЕЙ ДЕРЕВИННО-СОЛОМ'ЯНИХ ПЛИТ МОДИФІКУВАННЯМ КАРБАМІДОФОРМАЛЬДЕГІДНОГО КЛЕЮ ЕТАНОЛОМ
}

\begin{abstract}
Досліджено покращення властивостей деревинно-солом'яних плит модифікуванням карбамідоформальдегідного клею етанолом. Для виготовлення деревинно-солом'яних плит використано пшеничну солому, деревинні частинки, карбамідоформальдегідну смолу, хлорид амонію та етанол. Виготовляли тришарові деревинно-солом'яні плити завтовшки 16 мм і щільністю 650, 750 і 850 кг $/ \mathrm{M}^{3}$. Деревинні частинки і суміш деревинно-солом'яних частинок використано відповідно для зовнішніх і внутрішнього шарів плити. Співвідношення між шарами плити - 20:60:20 (зовнішній: внутрішній: зовнішній). Для зовнішніх шарів плити використано клей без етанолу. Для внутрішнього шару плити вміст етанолу становив 10 масових одиниць на 100 масових одиниць смоли. Такі самі плити отримано з використанням немодифікованого карбамідоформальдегідного клею для визначення впливу етанолу на властивості деревинно-солом'яної плити. Встановлено, що деревинно-солом'яні плити з карбамідоформальдегідним клеєм, модифікованим етанолом, володіють покращеними властивостями. Підвищення міцності за статичного згину було найзначнішим і становило 53 \%. Межа міцності за розтягу перпендикулярно до площини деревинно-солом'яної плити збільшилася менше, а саме на 33 \%. Водопоглинання і набрякання по товщині такої плити зменшилися незначно, і ці зміни не перевищували 10 \%. Отримані деревинно-солом'яні плити мають підвищені механічні показники порівняно з вимогами стандарту ДСТУ ЕN 312-2:2003.
\end{abstract}

Ключові слова: солома; деревинна стружка; режим пресування; фізико-механічні властивості.

Вступ. Попит на деревинні плити в європейських країнах до 2020 р. щорічно збільшуватиметься на $3 \%$ (Lespromkhoz, 2017) і споживання їх зросте до 99 млн $\mathrm{M}^{2}$, тоді як у $2005 \mathrm{p}$. споживання становило 70 млн м ${ }^{2}$ (Lesomaterialy, 2018). Однак розвиток виробництва стружкових плит гальмується нестачею деревини (Zheng, et al., 2007; Singha, \& Thakur, 2008).

В умовах аграрної України злакова солома $є$ найперспективнішою сировиною, яка здатна замінити деревину у виробництві деревинних композитів і зокрема стружкових плит. Хімічний склад соломи і деревини подібний. Запаси соломи щорічно поповнюються, вона $\epsilon$ відходом сільського господарства з обмеженим використанням, ціна соломи низька. У США, після багаси, злакову солому вважають другим найпридатнішим сільськогосподарським волокном для виготовлення деревинних композитів (Rowell, Young \& Rowell, 1997).

Істотною перепоною використання соломи у виробництві стружкових плит $є$ поверхневий жиро-восковий шар соломи з антиадгезійними властивостями, який не дає змоги в разі використання традиційних карбамідоформальдегідних клеїв отримати задовільне клейове з'єднання між солом'яною стружкою (Pease, 1998; Wang, et al., 2009). Однак якість склеювання можна покращити видаленням жиро-воскового шару способа- ми фізичної або хімічної обробки солом'яної стружки (Liu, et al., 2002; Patent Ukrainy na korysnu model: № 50489, 2009, № 93159, 2009, № 93160, 2009), а також заміною, або модифікуванням карбамідоформальдегідних клеїв клеями більшої реакційної здатності (Zhang, et al., 2011; Rexen, 1975; Pease, 1998).

Використання водяної пари, кислот, лугів для оброблення солом'яної стружки 3 метою видалення жировоскового шару значно покращують властивості виготовлених з такої стружки плит. Однак додаткові енергетичні затрати на отримання водяної пари, сушіння стружки, використання кородуючих речовин і додаткового обладнання для оброблення солом'яної стружки $\epsilon$ гальмівними факторами у впровадженні цих методів у виробництво.

Застосування ізоціанатних клеїв для склеювання солом'яної стружки дасть змогу зменшити температуру i час гарячого пресування плит, використати для склеювання вологішу стружку, що підвищить продуктивність виробничих ліній (Gallbraith, 1986). Але вартість ізоціанатних клеїв для склеювання деревини і соломи $€$ істотно більшою, ніж інших клеїв для деревини, таких як карбамідоформальдегідні, фенолоформальдегідні й меламіноформальдегідні, в масовому розрахунку (Han, et al., 1998). Це зменшує привабливість ізоціанатних

\section{Інформація про авторів:}

Козак Руслан Олегович, канд. техн. наук, доцент, кафедра технологій деревинних композиційних матеріалів, целюлози та паперу. Email: kozak_r@nltu.edu.ua

Бехта Павло Антонович, д-р техн. наук, професор, завідувач кафедри технологій деревинних композиційних матеріалів, целюлози та паперу. Email: bekhta@ukr.net; https://orcid.org/0000-0002-4320-5247

Цитування за ДСтУ: Козак Р. О., Бехта П. А. Покращення властивостей деревинно-солом'яних плит модифікуванням карбамідоформальдегідного клею етанолом. Науковий вісник НлтУ України. 2018, т. 28, № 5. С. 97-100.

Citation APA: Kozak, R. O., \& Bekhta, P. A. (2018). Improvement of wood-straw board properties using urea formaldehyde glue modified by ethanol. Scientific Bulletin of UNFU, 28(5), 97-100. https://doi.org/10.15421/40280521 
клеїв і змушує виробників плит не відмовлятися від дешевих і легких у виготовленні карбамідоформальдегідних клеїв (Guru, Tekeli \& Bilici, 2005).

Руйнування поверхневого жиро-воскового шару солом'яної стружки етанолом у процесі їі склеювання модифікованим карбамідоформальдегідним клеєм для досягнення низькозатратного виробництва деревинно-солом'яних плит $\epsilon$ інноваційним у цьому дослідженні (Раtent Ukrainy na vynakhid № 94372, 2010). При цьому міцність склеювання солом'яних частинок може бути збільшена без застосування водяної пари, кислот, лугів і дорогих клеїв з великою реакційною здатністю.

Мета дослідження - вивчити вплив модифікованого етанолом карбамідоформальдегідного клею на властивості деревинно-солом'яних плит.

Експериментальна частина. Використовували деревинну стружку промислового виготовлення із заводу стружкових плит. Солому пшениці отримано з місцевого господарства. Стебла початково подрібнили на довжину 20-30 мм на соломорізці та доподрібнили на лопатевій дробарці. Деревинну і солом'яну стружку окремо додатково висушували у сушильній шафі за температури $85{ }^{\circ} \mathrm{C}$ до приблизно $2 \%$ вологи, сортувалися на лабораторній механічній сортувалці 3 отворами сит $2 \times 2$ мм. Зберігалась стружка у пластикових пакетах окремо за видами (деревинна, солом'яна) і фракціями (зовнішній шар, внутрішній шар) у лабораторії.

Використовували карбамідоформальдегідну смолу промислового виробництва марки КФ-МТ зі сухим залишком $64 \%$, концентрацією водневих іонів (pH) 8.1, умовною в'язкістю за В3-246 (діаметр сопла 4 мм) 92 с, часом желатинізації за температури $100{ }^{\circ} \mathrm{C} 53 \mathrm{c}$.

Хлористий амоній, який використовували як затверджувач, та 96 \%-й етанол придбали у спеціалізованому магазині. Немодифікований клей готували змішуванням карбамідоформальдегідної смоли 3 попередньо приготованим $20 \%$-м водним розчином хлористого амонію. Для внутрішнього і зовнішнього шарів плити вміст затверджувача становив відповідно 1,5 і $0,25 \%$ від маси абсолютно сухої смоли (Grigoriou, 2000; Salabai, 2008).

Модифікований карбамідоформальдегідний клей готували змішуванням карбамідоформальдегідної смоли 3 попередньо приготованим $20 \%$-м водним розчином хлористого амонію і $96 \%$-м етанолом. Вміст затверджувача у клеї становив 1,5 \% від маси абсолютно сухої смоли. Вміст етанолу становив 10 мас.ч. на 100 мас. ч. розчину смоли. Значення вказаної масової частки етанолу отримано за результатами попередніх досліджень (Guru, Tekeli \& Bilici, 2005). Усі компоненти клею перемішували впродовж 10 хв.

Виготовляли тришарові деревинно-солом'яні плити розміром $300 \times 300 \times 16 \mathrm{MM,}$ щільністю $650,750 \mathrm{i}$ 850 кг $/ \mathrm{M}^{3}$ і співвідношенням між шарами плити 20:60:20 (зовнішній: внутрішній: зовнішній). При цьому деревинну стружку для зовнішніх шарів змішували з немодифікованим карбамідоформальдегідним клеєм. Для формування внутрішнього шару плити деревинну і солом'яну стружку перемішували за співвідношення 35:65 \%. і до неї додавали модифікований карбамідоформальдегідний клей. Витрата клею в шарах плити становила $14 \%$ від маси абсолютно сухої стружки (Yao, Xu \& Feng, 2003; Mo, et al., 2003). 3 приготованої стружково-клейової суміші формували стружковий ки- лим, підпресовували і спрямовували в прес для гарячого пресування. Пресування відбувалось 3 використанням дистанційних прокладок. Режим пресування наведено в таблиці.

Таблиця. Режим пресування деревинно-солом'яних плит

\begin{tabular}{|c|c|c|c|}
\hline \multirow{2}{*}{ Параметр режиму } & \multicolumn{3}{|c|}{ Щільність плит, кг/м ${ }^{3}$} \\
\hline & 650 & 750 & 850 \\
\hline $\begin{array}{l}\text { Питомий тиск пресування, } \\
\text { МПа }\end{array}$ & 2,2 & 2,2 & 2,2 \\
\hline Температура пресування, ${ }^{\circ} \mathrm{C}$ & 170 & 170 & 170 \\
\hline $\begin{array}{l}\text { Тривалість пресування, } \\
\text { хв/мм (хв) }\end{array}$ & $0,43(6,8)$ & $0,49(7,8)$ & $0,55(8,8)$ \\
\hline
\end{tabular}

Вологість готових плит становила 8 \%. Контрольні плити виготовляли за такою самою методикою без використання етанолу в клеї.

Перед розкроюванням плит на зразки виготовлені плити витримували в лабораторії впродовж 24 год. Виготовлення зразків і їх випробування здійснювали згідно $з$ методиками ДСТУ EN 310:2003 (EN 310:1992, IDT), BS EN 319:1993, ДСТУ 4761:2007 (EN 317:1993, MOD).

Результати та обговорення. Встановлено, що деревинно-солом'яні плити з використанням модифікованого клею мають покращені властивості порівняно 3 контрольними плитами. Найістотніше збільшується межа міцності за статичного згинання - 53 \%. Дещо менше зростання межі міцності - за розтягування перпендикулярно до площини плити - 33 \%. Водопоглинання і набрякання, зменшуються незначно й зміни ці не перевищують $10 \%$.

Отже, етанол, який міститься у клеї, за період від обсмолення стружки й до завершення пресування плит, впливає на жиро-восковий шар соломи, розчиняючи його. Внаслідок цього в місцях контакту клею 3 поверхнею соломи зменшується гідрофобний вплив жировоскового шару на їх адгезійну взаємодію. Решта гідрофобної поверхні соломи не змінюється. Під час пресування етанол випаровується із плит разом з вологою.

Механічні показники деревинно-солом'яних плит, склеєних модифікованим клеєм, вже за щільності


312-2:2003 (рис. 1 і 2). 3 подальшим збільшенням щільності плит їх механічні показники зростають. Зокрема, зі збільшенням щільності плит від 650 до 750 кг/м ${ }^{3}$ межа міцності за статичного згину зростає на $15 \%$, а межа міцності за розтягу перпендикулярно до пласті плити - на $9 \%$. Зі збільшенням щільності плит від 650 до 850 кг м $^{3}$ ці механічні показники зростають на 52 і $18 \%$ відповідно.



Рис. 1. Нормовані та експериментальні значення межі міцності за статичного згину досліджуваних деревинно-солом'яних плит 




Рис. 2. Нормовані та експериментальні значення межі міцності за розтягу перпендикулярно до пласті досліджуваних деревинно-солом'яних плит

Набухання і водопоглинання деревинно-солом'яних плит з використанням модифікованого клею зі збільшенням їх щільності зменшуються (рис. 3), що також вказує на покращення адгезійної взаємодії клею з поверхнею соломи. Показник набухання плити зменшується на $4 \%$ в разі збільшення ії щільності від 650 до $750 \mathrm{\kappa г} / \mathrm{m}^{3}$ і на $31 \%$ - від 650 до $850 \mathrm{\kappa г} / \mathrm{m}^{3}$. Водопоглинання плити зменшується на 9 і $52 \%$ зі збільшенням іiі щільності від 650 до 750 кг $/ \mathrm{M}^{3}$ і від 650 до 850 кг $/ \mathrm{M}^{3}$ відповідно.

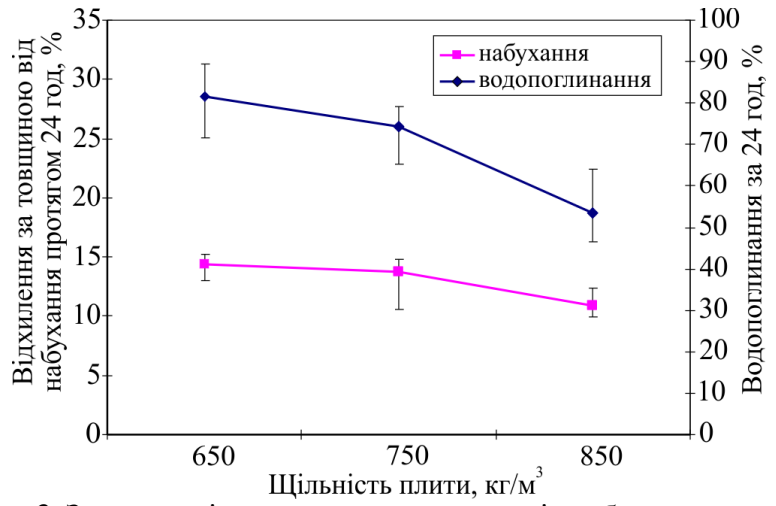

Рис. 3. Значення відхилення за товщиною від набухання та водопоглинання досліджуваних деревинно-солом'яних плит

Висновки. Модифікування карбамідоформальдегідного клею $96 \%$-м етанолом 3 витратою останнього 10 мас. ч. на 100 мас. ч. смоли покращує основні властивості деревинно-солом'яних плит. Зокрема, міцність за статичного згинання - на $53 \%$, міцність у разі розтягування перпендикулярно до площини плити - на 33 \%, водопоглинання і набрякання плит - до $10 \%$. Отримані деревинно-солом'яні плити мають підвищені механічні показники порівняно з вимогами стандарту ДСТУ EN 312-2:2003, що дає змогу розширити сировинну базу для виготовлення стружкових плит через залучення відходів сільськогосподарського виробництва, а саме соломи i, відповідно, економити деревинну сировину.

\section{Перелік використаних джерел}

Bekhta, P. A. (2007). Derevynno-solomiani plyty: Problemy i mozhlyvosti. Proceedings of the Forestry Academy of Sciences of Ukraine: Collection of Research Papers, 5, 127-130. [In Ukrainian].

Gallbraith, C. J. (1986). Recent developments in the full-time manufacture of all-isocyanate bonded structural composite boards. In: Proc. of the 20th Particleboard Symp., WSU, 55-81.

Grigoriou, A. H. (2000). Straw-wood composites bonded with various adhesive systems. Wood Science and Technology, 34, 355-365.
Guru, M, Tekeli, S., \& Bilici, I. (2005). Manufacturing of urea-formaldehyde-based composite particleboard from almond shell. $\mathrm{Ma}$ terials and Design, 27(10), 1148-1151. https://doi.org/10.1016/j.matdes.2005.03.003

Han, G., Zhang, C, Zhang, D., Umenura, D., \& Kawai, S. (1998). Upgrading of urea formaldehyde-bonded reed and wheat straw particleboards using silane coupling agents. Journal Wood Science, 44, 282-286.

Lesomaterialy. (2018). Mirovoi spros na lesomaterialy. Retrieved from: ftp://ftp.fao.org/docrep/fao/011/i0350r/i0350r02a.pdf. [In Russian].

Lespromkhoz. (2017). Informatcionnyi tcentr. Retrieved from: http://www.lesprom.com/en/news/Poyry_ezhegodniy_rost_spro$\underline{\text { sa na drevesnie pliti_v Evrope sosta- }}$ vit 3 60148/\#sthash.JIWeHZ1N.dpuf. [In Russian].

Liu, Z. M., Wang, F. H., \& Sun, R. Z. S. (2002). Analysis on structural features and surface elements of wheat straw. J. Northeast Forest Univ., 30, 62-65.

Mo, X., Cheng, E., Wang, D., \& Sun, X. S. (2003). Physical properties of medium-density wheat straw particleboard using different adhesive. Industrial Crops Products, 18, 47-53.

Patent Ukrainy na korysnu model № 50489. (2009). Ukraina, MPK V 27 N 3/00. Sposib vyhotovlennia derevynno-solomianykh plyt. Bekhta, P. A., Kozak, R. O., Salabai, R. H.; vlasnyk Natsionalnyi lisotekhnichnyi universytet Ukrainy. Nomer zaiavky u 2009 13209; zaiavl. 18.12.2009; opubl. 10.06.2010, Biul. № 11. [In Ukrainian].

Patent Ukrainy na vynakhid № 93159. (2009). Ukraina, MPK V 27 N 3/00. Sposib vyhotovlennia derevynno-solomianykh plyt. Bekhta, P. A., Kozak, R. O., Salabai, R. H.; vlasnyk Natsionalnyi lisotekhnichnyi universytet Ukrainy. Nomer zaiavky a 2009 13217; zaiavl. 18.12.2009; opubl. 10.01.2011, Biul. № 1. [In Ukrainian].

Patent Ukrainy na vynakhid № 93160. (2009). Ukraina, MPK V $27 \mathrm{~N}$ 3/00. Sposib vyhotovlennia derevynno-solomianykh plyt. Bekhta, P. A., Kozak, R. O., Salabai, R. H.; vlasnyk Natsionalnyi lisotekhnichnyi universytet Ukrainy. Nomer zaiavky a 2009 13230; zaiavl. 18.12.2009; opubl. 10.01.2011, Biul. № 1. [In Ukrainian].

Patent Ukrainy na vynakhid № 94372. (2010). Ukraina, MPK V $27 \mathrm{~K}$ 9/00. Sposib skleiuvannia solomianykh chastynok. Bekhta, P. A., Kozak, R. O.; vlasnyk Natsionalnyi lisotekhnichnyi universytet Ukrainy. Nomer zaiavky a 2009 09565; zaiavl. 30.07.2010; opubl. 26.04.2011, Biul. № 8. [In Ukrainian].

Pease, D. A. (1998). Recin advances support strawboard development. Wood Technology, 3, 32-34.

Rexen, F. (1975). Stroh als Rohstoffmaterial für Spanplatten. Holz Zentralbl. 101(34), 471-472.

Rowell, R. M., Young, R. A., \& Rowell, J. K. (1997). Paper and Composites from Agro-Based Resources. CRC Lewis Publishers, Boca Raton. New York, Tokyo. 464 p.

Salabai, R. H. (2008). Zakonomirnosti vplyvu tekhnolohichnykh parametriv na vlastyvosti derevynno-solomianykh plyt. Candidate Dissertation for Technical Sciences (05.23.06 - Technology of woodworking, furniture and wood products manufacturing). Lviv, $152 \mathrm{p}$. [In Ukrainian].

Singha, A. S., \& Thakur, V. K. (2008). Effect of fibre loading on properties of urea-formaldehyde matrix based green composites. Iranian Polymer Journal, 17(11), 861-873.

Wang, Z. L., Wang, E. J., Zhang, S. X., Wang, Z., \& Ren, Y. P. (2009). Effects of cross-linking on mechanical and physical properties of agricultural residues/recycled thermoplastics composites. Industrial Crops and Products, 29, 133-138. https://doi.org/10.1016/j.indcrop.2008.04.016

Yao, J., Xu, X. W., \& Feng, Y. Y. (2003). FTIR studies on the chemical composition of wheat straw in different layers. Spectro. Spec. Anal. 23, 58-60.

Zhang, Y., Gu, J., Tan, H., Di, M., Zhu, L., \& Weng, X. (2011). Straw based particleboard bonded with composite adhesives. BioResources, 6(1), 464-476.

Zheng, Y., Zhang, R. Z., Jenkins, B. M., and Blunk, S. (2007). Particleboard quality characteristics of saline jose tall wheatgrass and chemical treatment effect. Bioresource Technology, 98, 1304-1310. 


\section{УЛУЧШЕНИЕ СВОЙСТВ ДРЕВЕСНО-СОЛОМЕННЫХ ПЛИТ МОДИФИЦИРОВАНИЕМ КАРБАМИДОФОРМАЛЬДЕГИДНОГО КЛЕЯ ЭТАНОЛОМ}

Исследовано улучшение свойств древесно-соломенных плит модифицированием карбамидоформальдегидного клея этанолом. Для изготовления древесно-соломенных плит использованы пшеничная солома, древесные частицы, карбамидоформальдегидная смола, хлорид аммония и этанол. Изготовлялись трехслойные древесно-соломенные плиты толщиной 16 мм и плотностью 650,750 и 850 кг/м³. Древесные частицы и смесь древесно-соломенных частиц использованы соответственно для внешних и внутреннего слоев плиты. Соотношение между слоями плиты - 20:60:20 (внешний: внутренний: внешний). Для внешних слоев плиты использован клей без этанола. Для внутреннего слоя плиты содержание этанола составляло 10 массовых единиц на 100 массовых единиц смолы. Такие же плиты получены при использовании немодифицированного карбамидоформальдегидного клея для определения влияния этанола на свойства древесно-соломенной плиты. Установлено, что древесно-соломенные плиты с карбамидоформальдегидных клеем, модифицированным этанолом, обладают улучшенными свойствами. Повышение прочности при статическом изгибе было самым значительным и составило 53 \%. Предел прочности при растяжении перпендикулярно плоскости древесно-соломенной плиты увеличилась меньше, а именно на 33 \%. Водопоглощение и набухание по толщине такой плиты уменьшились незначительно, и эти изменения не превышали $10 \%$. Полученные древесно-соломенные плиты имеют повышенные механические показатели по сравнению с требованиями стандарта ДСТУ ЕN 312-2: 2003.

Ключевые слова: солома; древесная стружка; режим прессования; физико-механические свойства.

R. O. Kozak, P. A. Bekhta

Ukrainian National Forestry University, Lviv, Ukraine

\section{IMPROVEMENT OF WOOD-STRAW BOARD PROPERTIES USING UREA} FORMALDEHYDE GLUE MODIFIED BY ETHANOL

Improvement of wood-straw board properties using urea formaldehyde (UF) glue modified by ethanol was examined in this study. Wheat straw, wood particles, UF resin, ammonium chloride and ethanol were used for board production. Three-layer woodstraw boards with thickness $16 \mathrm{~mm}$ and density 650,750 and $850 \mathrm{~kg} / \mathrm{m} 3$ were produced. Wood particles and mixture of wood-straw particles were used respectively in the outer and inner layers of the board. The ratio between the layers of the board was 20:60:20 (outer: inner: outer). For the outer layers of board the glue without ethanol was used. For the inner layer of board the content of ethanol was 10 mass units on 100 mass units of resin. The same boards were produced using unmodified UF glue for the determination of ethanol effect on wood-straw board properties. We found that wood-straw boards with modified glue have better properties compared with control boards. The most significant increase of the MOR and is equal to $53 \%$. Slightly less is increase of the $\mathrm{IB}$, namely $33 \%$. Water absorption and thickness swelling reduce slightly and these changes do not exceed $10 \%$. Consequently, ethanol which is contained in glue, effects on the fat-wax layer of straw, dissolving it, for a period from mixing particles with glue and till the finishing of boards pressing. As a result, in the points of straw surface contact with the glue the hydrophobic effect of fatwax layer on their adhesive interaction decreases. The remaining hydrophobic surface straw is not changed. During the pressing the ethanol evaporates from the boards together with the moisture. Mechanical performance of wood-straw boards bonded with the modified glue meet the requirements of standard EN 312-2 at density of $650 \mathrm{~kg} / \mathrm{m}^{3}$. With further increasing of board density their mechanical properties increase. In particular, while board density increases from 650 to $750 \mathrm{~kg} / \mathrm{m}^{3}$ the MOR increases by $15 \%$, and IB - by $9 \%$. During board density increasing from 650 to $850 \mathrm{~kg} / \mathrm{m}^{3}$ these mechanical performances grow by $52 \%$ and $18 \%$ respectively. Thickness swelling and water absorption of wood-straw boards decrease using the modified glue with increasing their density, which also points on improve of the adhesion interactions of the glue and the straw surface. During board density increase from 650 to $750 \mathrm{~kg} / \mathrm{m}^{3}$ the thickness swelling index is reduced by $4 \%$ and by $31 \%$ - from 650 to $850 \mathrm{~kg} / \mathrm{m}^{3}$. During the density increasing from 650 to $750 \mathrm{~kg} / \mathrm{m}^{3}$ and from 650 to $850 \mathrm{~kg} / \mathrm{m}^{3}$ the boards water absorption decreases by $9 \%$ and $52 \%$ respectively.

Keywords: straw; wood particles; pressing mode; physical and mechanical properties. 